\title{
Post-event Flood Damage Surveys: A New Zealand Experience and Implications for Flood Risk Analysis
}

\author{
Ryan Paulik ${ }^{1,2, a}$, Kate Crowley $^{3}$ and Shaun Williams ${ }^{4}$ \\ ${ }^{1}$ National Institute of Water and Atmospheric Research (NIWA), 301 Evans Bay, Greta Point, Wellington 6021, New Zealand. \\ ${ }^{2}$ University of Auckland, Faculty of Engineering, Department of Civil and Environmental Engineering, 20 Symonds Street, Auckland 1010, \\ New Zealand \\ ${ }^{3}$ University of Edinburgh, School of GeoSciences, Institute of Geography, Drummond Street, Edinburgh EH8 9XP, United Kingdom. \\ ${ }^{4}$ National Institute of Water and Atmospheric Research (NIWA), 10 Kyle Street, Riccarton, Christchurch 8011, New Zealand.
}

\begin{abstract}
Disaster risk managers are shifting from hazard-centric identification of asset exposure, to quantitative risk assessments based on an understanding of asset vulnerability to impacts. For flood hazard management this shift is support by empirical data detailing the damage reponse of asset typologies when exposed to varying flood hazard intensities. This data is rarely available to reserchers therefore, developing this understanding requires its post-event collection following flood events. This study presents a survey methodology applied to five flood events in New Zealand to develop an empirical residential building damage database for post-hoc vulnerability analysis. Damage data collected is described for building and component attribute susceptibility to damage from exposure to flood inundation depths. Quantity survey guidelines were used during post-hoc analysis to convert observed component damage ratios to asset-level damage ratios. We observe for four strucutral and non-structural building components that internal finishes and service components contributed the most to asset-level damage ratios up to $1.5 \mathrm{~m}$ above building floor levels. These detailed component observations coupled with damage ratio estimates for residential building typologies can inform future post-hoc empirical or synthetic methods to develop relative damage curves.
\end{abstract}

\section{Introduction}

Climate change and unsustainable urban development in flood prone areas are expected to increase the future incidence and scale of damaging flood events (Arnell and Gosling 2016; Jongman et al. 2012). In anticipation, disaster risk managers are shifting from hazard-centric identification of asset exposure to quantitative risk assessments based on an understanding of asset vulnerability to impacts (Merz et al. 2010). This change is driven at both global and local levels in response to major international agreements such as the Sendai Framework for Disaster Risk Reduction 2015-2030. The Frameworks first priority for disaster risk management (DRM) is focussed on an understanding of disaster risk in all its dimensions of vulnerability, capacity, exposure of persons and assets, hazard characteristics and the environment (UNISDR, 2015). At local levels, statutory land use planning provisions are regularly implemented to avoid or mitigate potential adverse consequences from flood exposure (Fournier et al. 2016). A detailed understanding of the physical and non-physical attributes of asset typologies and their susceptibility to flood damage is required to inform risk-based decisions at these levels.

In New Zealand, land and resource use in floodplains, including building development, is governed by the Resource Management Act 1991, administered by regional councils and local authorities. In addition, local authorities are required to control building development for flood risk avoidance and mitigation, directed by the Building Act 2004. Under these statutes, regulatory and non-regulatory planning requirements must be informed by legally defensible evidence on local flood risk in order to enact

${ }^{a}$ Corresponding author: ryan.paulik $@$ niwa.co.nz

DOI 10.3311/FLOODRisk2020.7.6 provisions that avoid or mitigate the potential adverse consequences of building development in flood prone areas. This requires information at a 'micro-scale' or 'asset-level', to assess the risk of damage and loss for assets exposed to flood hazards, such as buildings (Merz et al. 2010).

Flood risk assessments are made possible through detailed vulnerability information on assets in flood-prone areas. Physical vulnerability and tangible (e.g. economic) or intangible loss (e.g. social disruption) are commonly represented as 'damage curves'. These curves typically measure a building's expected damage as hazard intensity increases (e.g. flood depth). Damage can be quantified as either the (a) economic cost required to completely restore buildings to a pre-damage condition (i.e. absolute damage) (Penning-Rowsell et al. 2003), or (b) proportion of damage as a percentage, or ratio of "cost to repair/cost to replace" (i.e. relative loss) (Messner et al. 2007). Damage curves are derived using empirical or synthetic data collection methods and post-hoc analysis. This may include damage data collected after flood events or based on damage data informed by expert judgments on building susceptibility to damage under different flood conditions (Merz et al. 2010). Applying both empirical and synthetic damage curves is recommended by McBean et al. (1986), who suggested using synthetic damage curves calibrated with observed flood damage data are most accurate in assessing damages.

Empirical damage curve development for building assets are reliant on damage observations. Detailed information about flood impacts, exposure (i.e. physical and non-physical attributes), and vulnerability collected from historic flood events are often limited for building 
vulnerability analysis and damage curve development. Empirical damage data collected for these purposes have been attempted through post-event damage surveys (Thieken et al. 2005; Zhai et al. 2005; Kreibich et al. 2010) or collation of loss compensation or insurance claim data (Hasanzadeh Nafari et al. 2016). Countries such as Germany (Kreibich et al. 2017), and Italy (Molinari et al. 2014) have developed asset-level empirical damage databases to analyse the relationships between flood hazard characteristics, building attributes and direct tangible damage. Outside of these countries asset-level databases are rare.

Post-event damage surveys support the physical collection of observations and measurements that enable relationships between flood characteristics and direct tangible damage to be established for specific asset typologies. Surveys of flood damaged buildings assets have demonstrated an ability to measure flood hazard intensities (e.g. flood depth) at building locations (Gissing and Blong, 2004; Laudan et al. 2017), while recording physical and non-physical building attributes (Molinari et al. 2014) and assigning a damage-level based on visual inspection (Laudan et al. 2017). While previous field surveys have implemented procedures for systematic collection of flood hazard characteristics and building attributes, few attempts are made to apply a field-based damage index or ratio for flood damaged buildings. Posthoc damage curve development from survey data is reliant on attributing a damage index or ratio to building typologies for analysis of relationships between flood characteristics and direct tangible damage.

This study presents a post-event flood damage survey methodology to develop an empirical residential building damage database. Survey data from five flood events in New Zealand is described based on flood hazard characteristics, building and component attributes and their susceptibility to damage from flood exposure. We will discuss the application of the damage database for flood damage curve development in New Zealand, a country without curves designed for local residential building typologies.

\section{Methods}

\subsection{Flood events surveyed}

Post-event damage surveys were conducted for five major flood events in New Zealand between April 2013 and April 2017 (Table 1). 'Major' flood events are categorised as those where $>50$ residential buildings sustained direct tangible damage from flooding hazards. Events causing damage to fewer buildings occurred during this period however, resourcing (i.e. surveyors and financing) limited surveys to major events where damage was expected for a wider range of building typologies.

Flood events surveyed represent range of flooding type. These are characterised as urban stormwater (two events), riverine (two events) and riverine-levee breach (two events). Riverine and riverine-levee breach typically occurred in larger river catchments following prolonged ( $>24$ hour) rainfall caused by extra-tropical cyclones (e.g. Edgecumbe 2017) or mid latitude low pressure systems
(Whanganui 2015). Urban stormwater events were attributed to shorter duration ( $<12$ hour) high intensity rainfall events saturating soils and causing overland flows from urban drainage and road structures.

\begin{tabular}{ccllc}
\hline Flood Event & Date & Location/Territory & Flood Type & $\begin{array}{c}\text { Damage } \\
\text { Samples (No.) }\end{array}$ \\
\hline $\begin{array}{c}\text { Nelson- } \\
\text { Tasman }\end{array}$ & $\begin{array}{c}\text { April 21 } 213 \\
2013\end{array}$ & $\begin{array}{l}\text { Stoke, Nelson City; } \\
\text { Richmond, Tasman } \\
\text { District }\end{array}$ & Urban Stormwater & 57 \\
\hline Christchurch & $\begin{array}{c}\text { March } 4 \\
2014\end{array}$ & Christchurch City & $\begin{array}{l}\text { Urban Stormwater; } \\
\text { Riverine }\end{array}$ & 102 \\
\hline South & $\begin{array}{c}\text { June 3 } \\
\text { Dunedin }\end{array}$ & $\begin{array}{l}\text { South Dunedin, } \\
\text { Dunedin City }\end{array}$ & Urban Stormwater & 208 \\
\hline Whanganui & $\begin{array}{c}\text { June 20 } \\
2015\end{array}$ & $\begin{array}{l}\text { Whanganui, } \\
\text { Whanganui District }\end{array}$ & $\begin{array}{l}\text { Riverine-Levee } \\
\text { Breach; Riverine }\end{array}$ & 87 \\
\hline Edgecumbe & $\begin{array}{c}\text { April 6 } 6 \\
2017\end{array}$ & $\begin{array}{l}\text { Edgecumbe, } \\
\text { Whakatane District }\end{array}$ & $\begin{array}{l}\text { Riverine-Levee } \\
\text { Breach }\end{array}$ & 220 \\
\hline
\end{tabular}

Table 1. New Zealand flood events selected for building damage surveys.

\subsection{On-site building damage data collection}

Post-event damage surveys transitioned from paper-based forms (pre-2015) to open source/access field data collection applications such as RiACT (Lin et al. 2019) and QField (QField, 2020). The transition to field applications provided efficiencies in pre-survey data preparation for on-site damage surveys, as well as postprocessing and analysis in GIS software applications. Pre2015 building objects were digitised and spatially joined with post-2015 objects in QGIS to create a nationally consistent residential building damage database.

On-site damage surveys were conducted 7 to 18 days after flood events. Survey timing varied, with longer delays for riverine-levee breach events allowing for emergency response and recovery activities to proceed unhindered. Surveys were implemented by two to three researchers using paper-based forms (pre-2015) or mobile tablet computers to collect georeferenced building damage data. For the latter, spatial layers representing building feature locations and attributes were pre-installed in field collection applications (e.g. RiACT; QField) for ease of editing during the on-site survey.

Flood inundation depths were measured at each building site. Inundation depth is the flood hazard intensity parameter commonly applied in building flood damage curve development (Merz et al. 2010). This parameter supports 'depth-damage' curve development in post-hoc data analysis. Maximum inundation depths above ground level and first finished floor level were measured for damage buildings.

Where access permitted, maximum inundation depths were measured inside buildings. Depth levels were indicated by highwater marks and debris lines visible on external and internal walls. When internal building access was not permitted, depth above first finished floor level were measured from an external door-step. Other flood hazard characteristics such as flow velocities, sediment loads and deposition, contamination and erosion or scour could not be reliably determined in the aftermath of surveyed flood events. Nevertheless, presence of debris 
(i.e. sediment deposition), contamination and scour were recorded when observed.

Recorded building attributes included coordinates, address (for internal use only), and building attributes including construction period, construction type, floor height (metres above ground), floor type, number of storeys, wall cladding and use category (Table 2). These attributes when pre-assigned to building objects were validated and update as necessary on-site. Except for the building address, floor height and storeys attributes, information was collected using nominal and intervalscaled data structures.

Surveyed buildings were assigned flood damage ratio estimate from 0 (i.e. no damage) to 1 (complete damage and/or replacement). A damage ratio is defined here as the relative percentage of building value requiring repair or replacement (i.e. 'cost to repair'/'cost to replace'). Asset-level damage ratios were estimated from the physical damage or replacement observed for a buildings structure, external finishes, internal finishes and service components as described by Quotable Value 'Costbuilder' quantity survey guidelines (Table 2). 'Costbuilder' estimates the relative proportion of these components to the overall construction cost of different residential building construction designs.

Onsite building component damage ratios were visually assessed using an ordinal scale between 0 and 1 . The scale increases in 0.25 (i.e. $25 \%$ ) intervals to assist surveyors with assigning component damage ratios onsite. Ordinal component damage ratios were estimated based on the proportion observed damage or required replacement. The assigned ratio defaults to the maximum value of the ratio interval. For example, if between 0.5 and 0.75 of internal wall finishes were damaged or replaced at the time of building survey, 0.75 is assigned. Component damage ratio estimates were multiplied by 'Costbuilder' construction cost ratios to estimate their asset-level damage ratio. Asset-level damage ratios were then calculated from the sum of component damage ratios. This approach supported the systematic estimation of assetlevel damage ratios for residential buildings damaged in five major New Zealand flood events.

\section{Results}

Post-event surveys for the five flood events collected 674 building damage samples. These samples, including information on flood inundation depth (i.e. above ground, above first finished floor level), physical (i.e. construction type, floor height, floor type, storeys, wall cladding) and non-physical (i.e. use category, construction period) building attributes (Table 2) and component damage ratios. These were considered the minimum information requirements for classifying building typologies and supporting future vulnerability analysis of direct tangible damage from flood hazard exposure. Results associated with the damage sample characteristics including flood hazards, residential building typologies, building component damage and damage ratios are presented.

\subsection{Flood hazards}

Maximum flood inundation depth above ground and above first finished floor level was consistently measured for each damaged building. Depth above ground ranged from $0.05 \mathrm{~m}$ to $2 \mathrm{~m}$, and above finished floor levels from -0.35 $\mathrm{m}$ to $1.7 \mathrm{~m}$ (Figure 1). The average inundation depths

\begin{tabular}{|c|c|}
\hline Variable & Attribute or Description \\
\hline Use Category & Residential \\
\hline Construction Frame & Concrete Masonry (12); Timber (662) \\
\hline Wall Cladding & Brick Masonry (151); Concrete Masonry (12); Fibre-cement (147); Stucco-roughcast (104); Timber (258); Other (12) \\
\hline Storeys & $1(629) ; 2(90)$ \\
\hline Floor Level Height & First Finished Floor Level Height Above Ground \\
\hline Foundation Type & Pile (556), Concrete Slab (118) \\
\hline Period of Construction & $1900-1920(14) ; 1920-1940(138) ; 1940-1960(113) ; 1960-1980(203) ; 1980-2000(151) ;>2000(55)$ \\
\hline Depth above ground & Flood Inundation Depth Above Ground \\
\hline Depth above floor level & Flood Inundation Depth Above First Finished Floor Level \\
\hline \multirow{3}{*}{ Structure } & Substructure: All work below the underside of the lowest floor finish. \\
\hline & Frame: All load bearing column and beam framework above lowest floor finish, major roof framing members. \\
\hline & Upper Floor: Suspended floors, mezzanine floors, balcony floors and roof slabs. \\
\hline \multirow{3}{*}{ External Finishes } & Roof: Complete weatherproof covering of all types to roofs. \\
\hline & Walls: All work to exterior walls, including applied or in situ finishes. \\
\hline & Windows and doors: All windows and doors in exterior walls, including vertical or near vertical glazing. \\
\hline \multirow{7}{*}{ Internal Finishes } & Stairs: Flights and intermediate landings including integral finishes. \\
\hline & Walls: All non-structural internal walls. \\
\hline & Doors: All interior doors including frames, architraves, finishes and hardware. \\
\hline & Floor finishes: Includes all preparatory work, screeds, surface finishes and raised floors. \\
\hline & Wall finishes: Includes all preparatory work and finishes to interior walls. \\
\hline & Ceiling finishes: Includes all preparatory work and finishes to ceilings. \\
\hline & Fixtures and fittings: Joinery fittings, built-in or fixed in position, includes glass, hardware and finishes. \\
\hline Services & $\begin{array}{l}\text { Plumbing: Hot and cold water supply, including hot water cylinder, sanitary fittings, soil, waste and vent pipes. } \\
\text { Electrical and heating: All electrical services providing lighting, power, heating and air-conditioning. }\end{array}$ \\
\hline
\end{tabular}

Table 2. Surveyed residential building attributes and component descriptions. Their frequency of occurrence from five New Zealand flood events is 674 unless specified in brackets. 
above floor levels was $0.26 \mathrm{~m}$ (std. dev. $=0.29 \mathrm{~m}$ ) for all events. The relatively low average depth could be attributed to a higher number of damage samples from urban stormwater events compared to flooding from riverine sources. In riverine-levee breach events buildings were exposed to higher above floor inundation depths, compared to urban stormwater events (Figure 1).

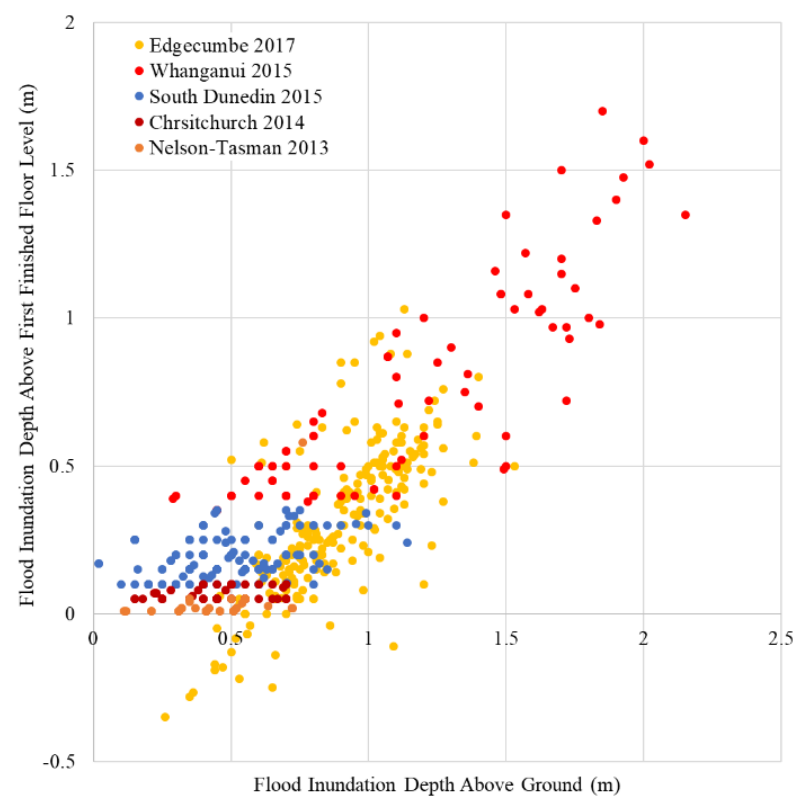

Figure 1. Flood inundation depths above ground and first finished floor levels for surveyed buildings

Inundation depths above floor levels varies due to building foundation types. Building floor levels on 'concrete slab' foundations were elevated on average 0.23 $\mathrm{m}$ above ground level, compared to $0.47 \mathrm{~m}$ for 'pile' foundations. This resulted in slightly higher average inundation depths above floor level $(0.31 \mathrm{~m})$ for buildings on concrete slab foundations, relative to those on piles $(0.24 \mathrm{~m})$. Inundation depths above concrete slab floor levels were also caused by lower flood inundation depths above ground. Average inundation depths at these building sites were $0.48 \mathrm{~m}$ above ground, compared to $0.71 \mathrm{~m}$ for pile floor levels. This demonstrates a higher likelihood of damaging water ingress at relatively lower inundation depths for buildings constructed on concrete slab foundations.

Other flooding characteristics, such as flow velocities, sedimentation, contamination and scour could not reliably be quantified in the aftermath of the event. Sediment deposition was evident inside most buildings but could not be directly measured due to clean-up activities. Anecdotal reports from building residents suggest deposition thickness ranging from $0.01 \mathrm{~m}-0.1 \mathrm{~m}$ occurred inside buildings exposed to riverine-levee breach events, and $<0.01 \mathrm{~m}$ inside buildings exposed to urban stormwater events. In urban stormwater events, building residents often reported sewage mixed with sediment deposits.

Scour of building foundations was observed for buildings exposed to a riverine-levee breach event in Edgecumbe 2017. Scouring at building sites opposite the levee breach appeared to focus where below ground level infrastructure services (e.g. potable and wastewater pipelines, electrical cables) were constructed in trenches covered by loosely compacted soil. Service trench scouring close to buildings undermined timber and concrete pile foundations in some cases. Pile foundation scouring also where flows were constrained between buildings, potentially creating high flow velocities.

\subsection{Residential building typologies}

Flood damaged residential buildings surveyed can be categorised into 12 typology classes based on their period of construction and physical attributes; construction type, floor type and storeys (Table 3). These classes represent common building component materials used in New Zealand construction phases, as well as building size (i.e. number of storeys). Classes were used to inform component construction cost ratios from 'Costbuilder', while also attempting to minimise damage variance for a given flood depth.

\begin{tabular}{|c|c|c|c|c|c|c|}
\hline $\begin{array}{l}\text { Building } \\
\text { Typology }\end{array}$ & $\begin{array}{c}\text { Construction } \\
\text { Type }\end{array}$ & $\begin{array}{c}\text { Foundation } \\
\text { Type }\end{array}$ & Storeys & $\begin{array}{c}\text { Period of } \\
\text { Construction } \\
\text { (Year) }\end{array}$ & $\begin{array}{c}\text { Damage } \\
\text { Samples } \\
(\#)\end{array}$ & $\begin{array}{c}\text { Percentage } \\
(\%)\end{array}$ \\
\hline Class 1 & Timber & Pile & 1 & $<1960$ & 258 & 38.3 \\
\hline Class 2 & Timber & Pile & 2 & $<1960$ & 6 & 0.9 \\
\hline Class 3 & Timber & Pile & 1 & $1960<2000$ & 256 & 38 \\
\hline Class 4 & Timber & Pile & 2 & $1960<2000$ & 23 & 3.4 \\
\hline Class 5 & Timber & Pile & 1 & $>2000$ & 13 & 1.9 \\
\hline Class 6 & Timber & Pile & 2 & $>2000$ & 1 & 0.1 \\
\hline Class 7 & Timber & $\begin{array}{l}\text { Concrete } \\
\text { Slab }\end{array}$ & 1 & $1960<2000$ & 53 & 7.9 \\
\hline Class 8 & Timber & $\begin{array}{l}\text { Concrete } \\
\text { Slab }\end{array}$ & 2 & $1960<2000$ & 10 & 1.5 \\
\hline Class 9 & Timber & $\begin{array}{c}\text { Concrete } \\
\text { Slab }\end{array}$ & 1 & $>2000$ & 40 & 5.9 \\
\hline Class 10 & Timber & $\begin{array}{c}\text { Concrete } \\
\text { Slab }\end{array}$ & 2 & $>2000$ & 1 & 0.1 \\
\hline Class 11 & $\begin{array}{l}\text { Concrete } \\
\text { Masonry }\end{array}$ & $\begin{array}{l}\text { Concrete } \\
\text { Slab }\end{array}$ & 1 & - & 9 & 1.3 \\
\hline Class 12 & $\begin{array}{l}\text { Concrete } \\
\text { Masonry }\end{array}$ & $\begin{array}{c}\text { Concrete } \\
\text { Slab }\end{array}$ & 2 & - & 4 & 0.6 \\
\hline Total & & & & & 674 & 100 \\
\hline
\end{tabular}

Table 3. Residential building typologies identified from buildings damaged in the five flood events.

Timber-frame buildings comprised $98 \%$ of the damage sample. Over $75 \%$ were constructed prior to 2000 and are single storey on pile foundations (i.e. Classes 1 and 3). Class 1 buildings were often constructed with durable hardwood timbers and in many cases had undergone significant upgrades incorporating modern building materials and services. Class 3 buildings often comprised less durable composite timber materials such as low or medium density fibreboard for internal finishes (e.g. flooring, fixtures). Timber-frame constructions on concrete slab foundations (Classes 7 to 10) were more prevalent after 1960 and was the most common foundation type after 2000. Multi-storey and non-timber construction frame buildings only account for $8 \%$ of the damage sample. New Zealand's high seismic risk and building code encourages low-rise (i.e. 1 or 2 storey) timber-frame residential building construction, resulting in few multistorey or masonry-frame buildings. 


\subsection{Building component damage and observed damage ratios for residential buildings}

Here we describe damage observed to building structure, external finishes, internal finishes and services. We also present observed building component damage ratios in Figure $2 \mathrm{a}$ to Figure 2e for structure and external finishes and Figure $3 \mathrm{a}$ to Figure $3 \mathrm{~h}$ for internal finishes and services. Damage ratios are reported as the proportion of ordinal damage ratios (i.e. $0,0.25,0.5,0.75,1$ ) recorded for $0.5 \mathrm{~m}$ inundation depth intervals above building firstfinished floor levels.

Structure damage was observed for eighteen buildings affected in the Edgecumbe 2017 riverine-levee breach event. Substructure and frame damage ratios range widely between 0.25 to 1 for inundation depths less than 1 $\mathrm{m}$ above floor level (Figure 2a, 2b). Damage typically occured from scouring along infrastructure service trenches, removing pile foundations and causing breakage
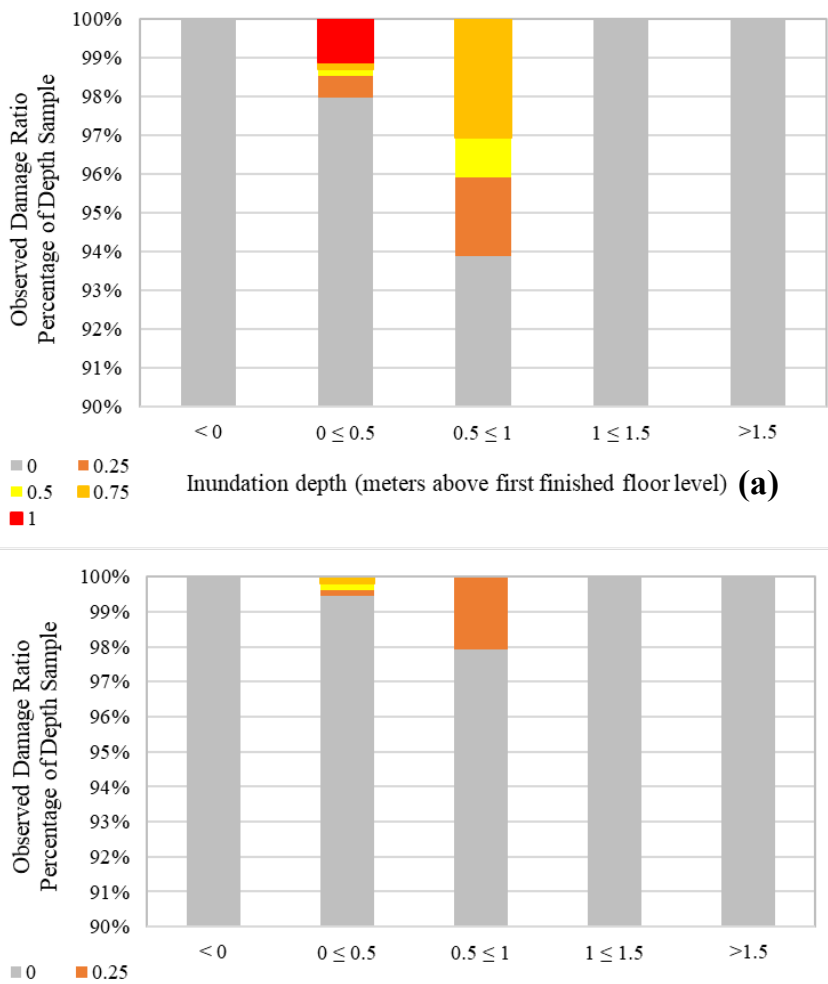

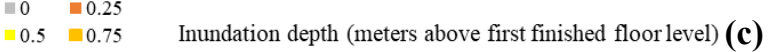

or displacement of the timber substructure and frame. In at least one case, direct hydrodynamic action from high flow velocities partially dislodged a timber-frame single storey building from its pile foundations. In both structure damage cases, building failures resulted in damage to roof frame and cladding (Figure 2c). No structure component damage was observed for other flood events.

External window and door finishes were highly susceptible to damage upon flood water contact. Glass panes exposed to water required complete replacement in all cases, as did hardwood and composite timber doors when water absorption cause warping. Damage ratios for these components reached or exceeded 0.25 for most buildings when inundation depths exceeded floor levels (Figure 2e). As depths exceed $1 \mathrm{~m}$ above floor level, damage ratios for window and door finishes of 0.5 or greater were observed on over $65 \%$ of buildings. Inundation depths above floor level also resulted damage to external wall cladding (Figure 2d). Typically, indirect
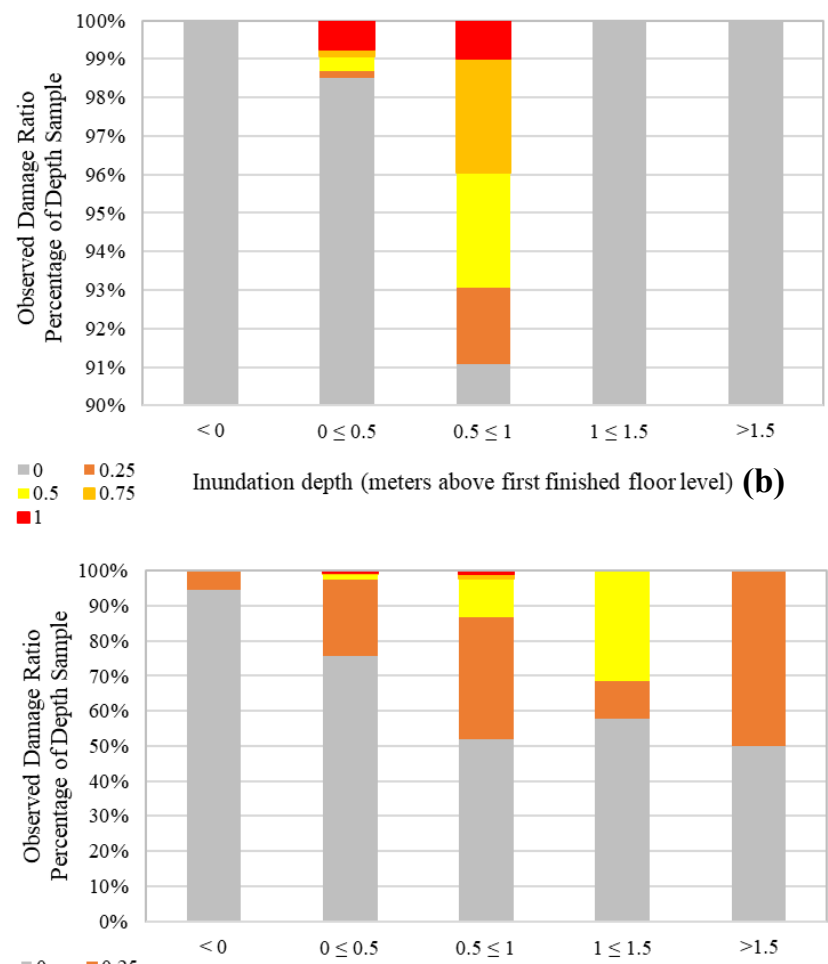

$0.5 \quad 0.75$ Inundation depth (meters above first finished floor level) (d)

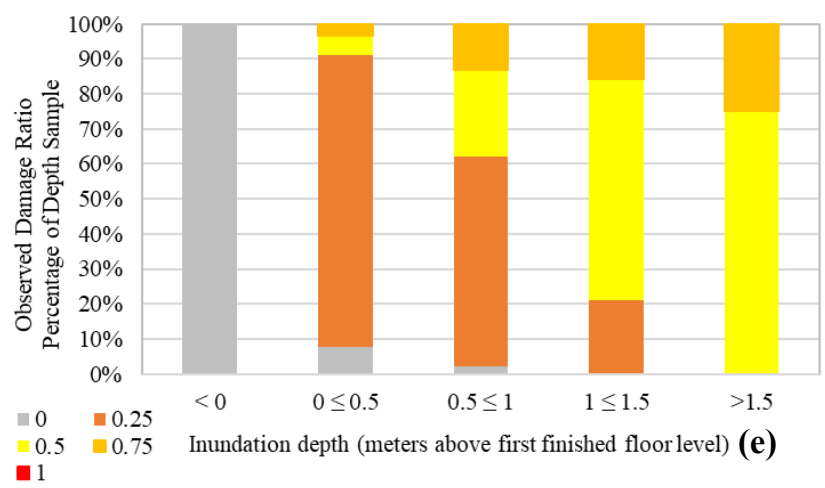

Figure 2. Field observed damage ratios for structure (substructure (a), frame (b)) and external finishes (roof (c), walls (d), windows and doors (e)) components. 
damage was observed from the removal and repair of timber weatherboards to facilitate the replacement or repair of building membranes and drying or sanitation of timber-frames.

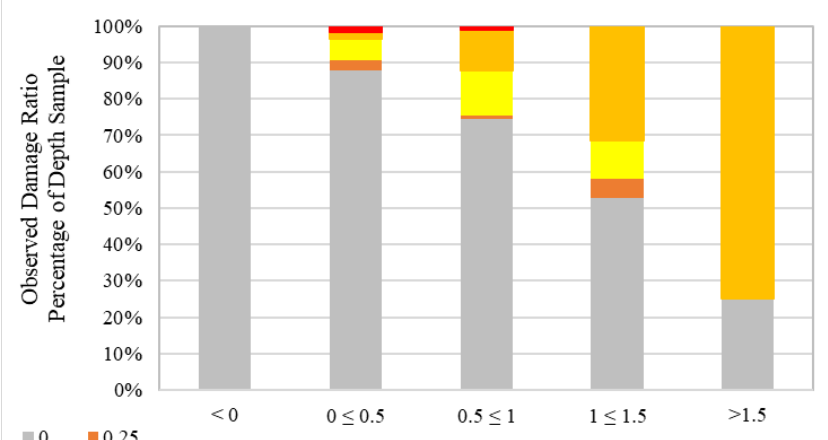

$\begin{array}{lll}0 & =0.25 \\ 0 & =0.5 & =0.75\end{array}$ $=0.5 \quad \square 0.7$

$\square 1$

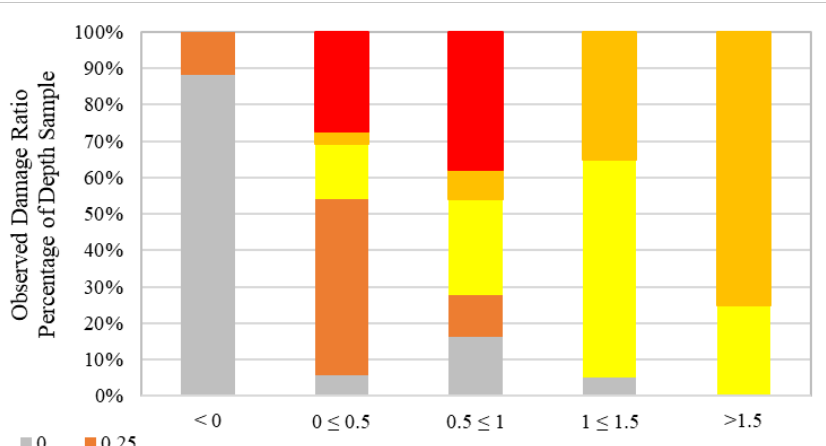

$\begin{array}{lr}=0 & \square .25 \\ 0.5 & 0.75\end{array}$

$\square 1$

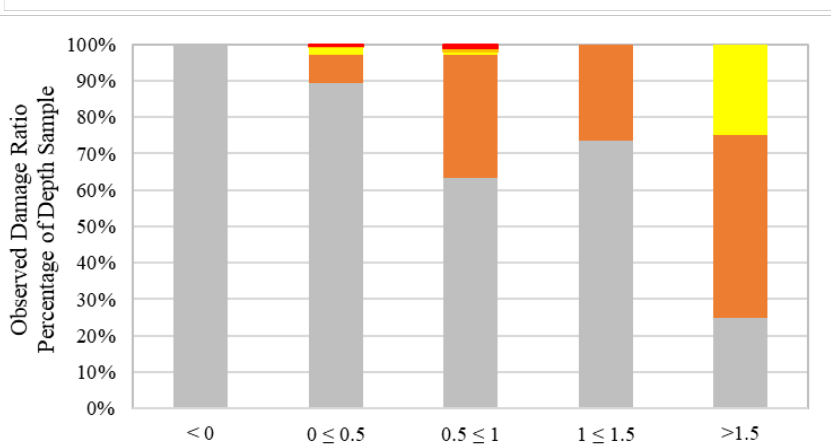

$=0 \quad=0.25$

$0 \leq 0.5$

$0.5 \leq 1$

$\leq 1.5$

$=0.5$

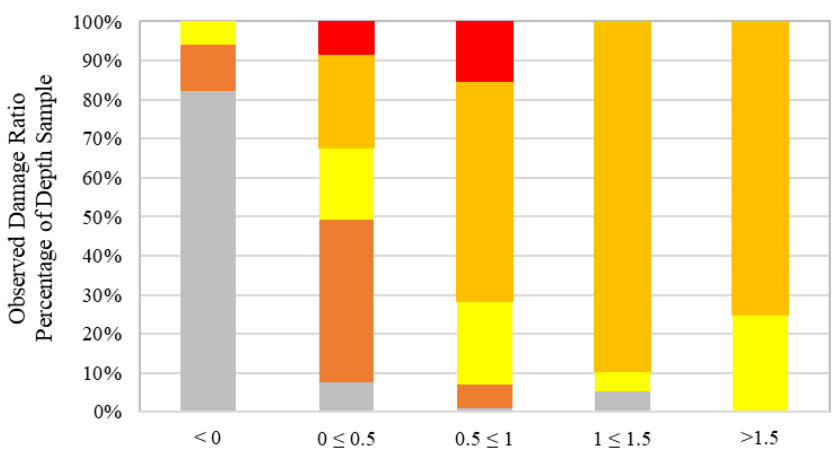

$=0 \quad \square 0.25$

$=0.5 \quad=0.75$

1
Internal finishes including internal doors, floor finishes, wall finishes, and fittings and fixtures were highly susceptible to damage. Notably, doors (Figure 3b) and floor finishes (Figure 3c) composed of composite-timber materials were usually replacement upon contact with

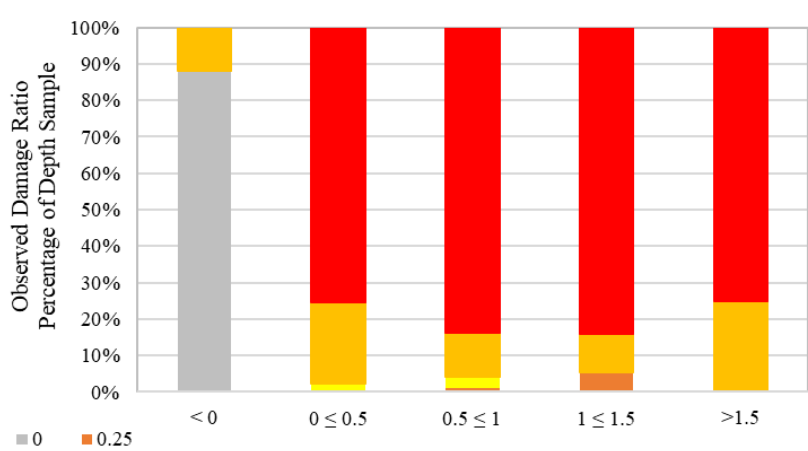

$0.5 \quad 0.75$ Inundation depth (meters above first finished floor level) (b) -1

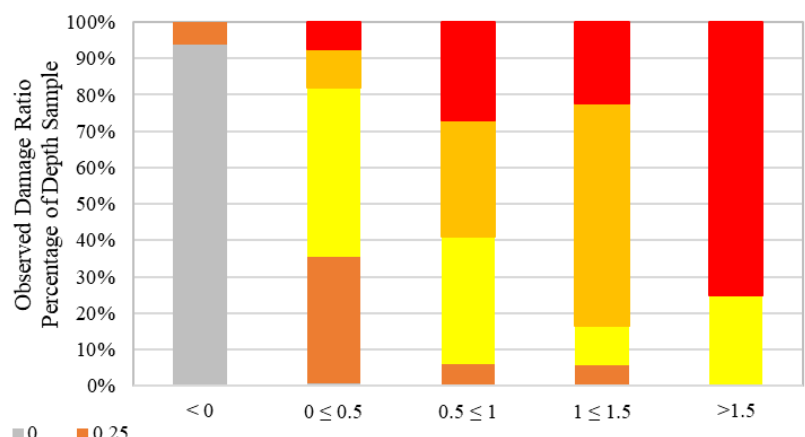

$=0 \quad=0.25$

$0.5 \quad 0.75 \quad$ Inundation depth (meters above first finished floor level) $(\mathbf{d})$

-1

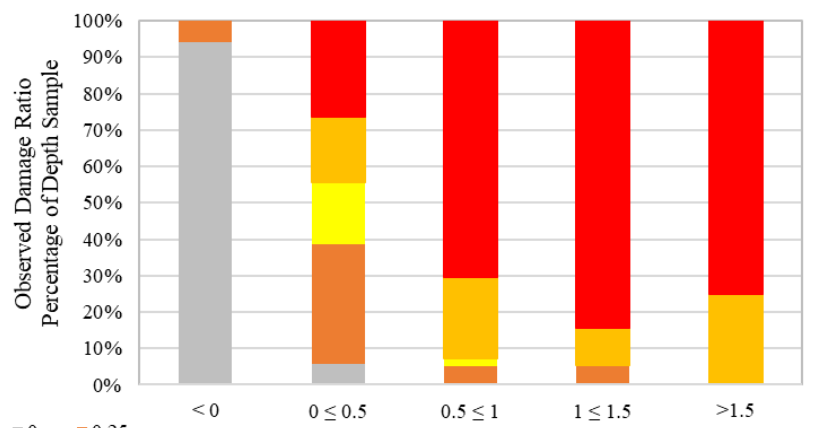

$\begin{array}{ll}=0 & =0.25 \\ 0.5 & 0.75\end{array}$

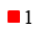

Inundation depth (meters above first finished floor level) (f)

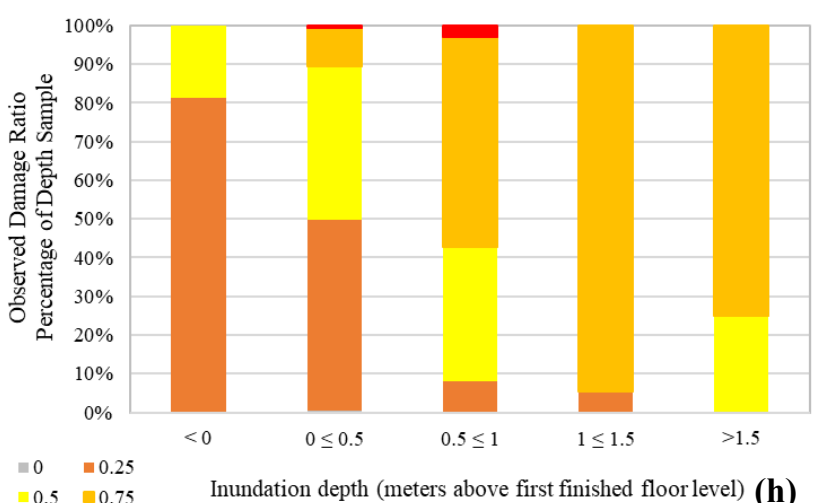

Figure 3. Field observed damage ratios for internal finishes (walls (a), doors (b), floor finishes (c), wall finishes (d), ceiling finishes (e), fixtures and fittings (f)) and services (plumbing (g), electrical and heating (h)) components. 
flood waters. These materials were common floor finishes in Class 3 and 4 buildings, and their damage often caused indirect damage to internal walls (Figure 3a) and ceiling finishes (Figure 3e) during their replacement and repair. Hardwood floor finishes common in Class 1 and 2 buildings and plywood finishes in Class 5 and 6 buildings were less susceptible to damage, with the former requiring partial replacement due to water absorption and warping when depths above floor level exceeded $0.5 \mathrm{~m}$. In all buildings, wall finishes (Figure 3d) and fixtures and fittings (Figure 3f) composed of either composite or hardwood timber materials were usually damaged and replaced on contact with flood waters.

Electrical and heating, and plumbing services were inundated for most buildings. Below floor levels, flood waters damaged on or near-to ground condenser units for heating and air-conditioning systems, causing electrical and heating damage ratios up to 0.5 (Figure $3 \mathrm{~g}$ ). Although electrical wiring was reusable in many cases after safety testing, often it sustained partial damaged and was replaced during building repairs. Electrical fittings were replaced on contact with flood water. Plumbing services were damage from either direct flood water exposure or the demolition and repair other components. Damage ratios exceeding 0.25 were observed for most buildings when inundation depths immediately exceeded floor level, and 0.75 where depths exceed $>0.5 \mathrm{~m}$. Many cases with higher damage ratios occurred due to indirect damage and/or service replacement during building repairs.

\subsection{Asset-level damage ratios for residential buildings}

Asset-level damage ratios were estimate from observed component damage ratios. For twelve potential building typology classes were identified from surveyed building attributes, four classes (1, 3, 7 and 9) representing single storey timber-frame buildings each exceed $5 \%$ of the total building damage sample (Table 2). Here, component damage ratios for these classes are converted into assetlevel damage ratios using quantity survey guidelines (Quotable Value, 2017). In this section, estimated assetlevel mean damage ratios for structure, external finishes, internal finishes and structure components for $0.5 \mathrm{~m}$ inundation depth intervals above floor level are reported (Figure 4a to Figure 4d).

Service components form $6 \%$ to $9 \%$ of construction costs, and sustained damage below or at floor level. Mean damage ratios of 0.02 are estimated below floor levels for Class 1 and 3 buildings, due to inundation of electrical and heating equipment, and under floor insulation materials (Figure 4a, b). Flood waters exceeding floor levels cause a rapid increase in damage, mostly from internal finishes and service component exposure. Mean damage ratios between 0.21 (Class 7) and 0.28 (Class 9) were observed for inundation depths up to $0.5 \mathrm{~m}$ above floor level. At these depths, internal finishes accounted for $68 \%$ to $70 \%$ of all component damage and contributed over $60 \%$ at depths up to $1 \mathrm{~m}$ to $1.5 \mathrm{~m}$.

Class 9 buildings nearly reach a 0.4 mean damage ratio between $0.5 \mathrm{~m}$ to $1 \mathrm{~m}$ inundation depth above floor level (Figure 4d). Class 1 buildings exceeded this ratio at $1.5 \mathrm{~m}$ inundation depth above floor level (Figure 4a). External finishes formed $23 \%$ and $29 \%$ of building construction costs. Low-to-ground concrete slab foundations typical of Class 9 buildings constructed after the year 2000 caused greater exposure of external windows and doors to flood waters, causing higher damage ratios for external finishes relative to other building classes. The higher elevation of windows and doors on Class 1 buildings means that comparable component damage ratios were not experienced until inundation depth above floor levels reach $1.5 \mathrm{~m}$.

Structure component damage for Class 1,2 and 3 buildings are attributed to the riverine-levee breach event at Edgecumbe 2017. The asset-level contribution of structure components to mean damage ratios is minimal for each class, contributing 0.01 between $0.5 \mathrm{~m}$ to $1 \mathrm{~m}$ inundation depth above floor level. Quantity survey guidelines for these classes suggest the structure component forms $9 \%$ to $16 \%$ of building construction costs. These are considerably lower than internal finishes which contribute between $29 \%$ to $37 \%$. Relatively higher construction costs and damage susceptibility on contact with flood waters, causes noticeably higher asset-level damage ratios for internal finishes compared to other building components.

\section{Discussion}

In the present study, a systematic post-event survey methodology was applied to estimate asset-level damage ratios for residential building typologies. This approach extends on previous field-based studies where descriptive damage levels are attributed to exposed buildings (Lauden et al. 2017), by estimating asset-level damage ratios (i.e. 'cost to repair'/'cost to replace') from observed structural and non-structural component damage. Maximum component damage ratios estimated in the field using an ordinal scale were multiplied by component construction cost ratios in quantity survey guidelines to estimate assetlevel damage ratios for residential building typology classes. We observed that internal finishes, which can account approximately one-third of building construction costs, are highly susceptible to damage on contact with flood waters. Internal finishes contributed the highest proportion of asset-level mean damage ratios estimated for above floor level inundation depths up to $1.5 \mathrm{~m}$. These detailed component observations coupled with damage ratio estimates for residential building typologies could inform future post-hoc empirical or synthetic methods to develop relative damage curves for residential buildings (Thieken et al. 2008; Penning-Rowsell et al. 2003).

The residential building damage sample presented in this study has several limitations. Firstly, the maximum measured inundation depth above floor level was $1.7 \mathrm{~m}$, and depths exceeded $1 \mathrm{~m}$ in only $3 \%$ of buildings. This limits most component damage observations to relatively low inundation depths with $82 \%$ measuring below $0.5 \mathrm{~m}$. Secondly, twelve potential residential building classes were identified from common attribute types however, four classes account $90 \%$ of damaged buildings. These 

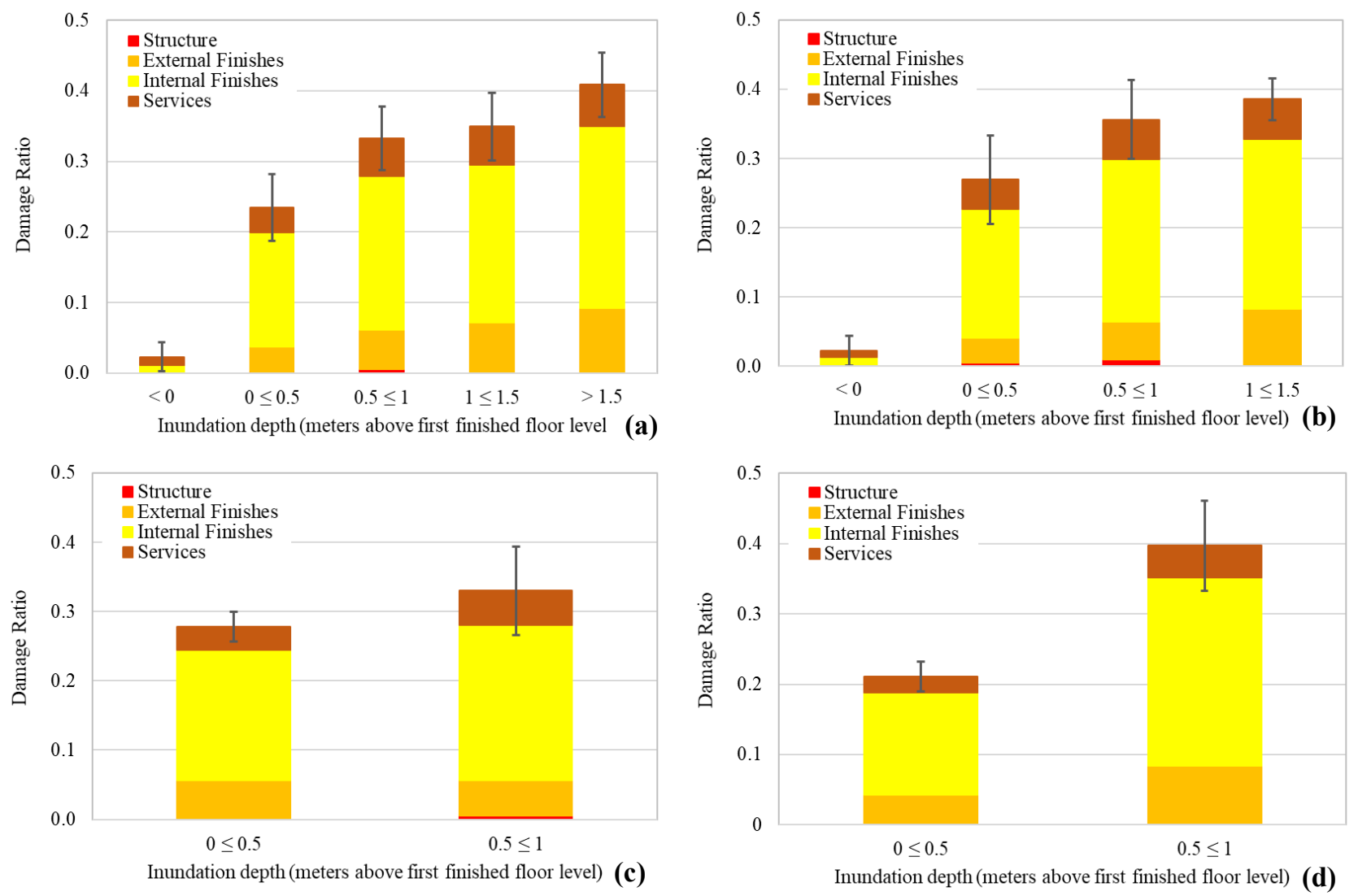

Figure 4. Mean damage ratios for building classes 1 (a), 3(b), 7(c) and 9(d). Error bars represent one standard deviation.

classes are all representative of single storey timber-frame buildings. Limited building typologies and flood hazard conditions could hinder the future development of empirical damage curves which represent present and future residential building and inundation depth characteristics in New Zealand floodplains (e.g. Merz et al. 2010). Unless future post-event surveys can address these limitations, the damage database presented in this study is likely to support the development of local synthetic damage curves calibrated with observed flood damage data as suggested by McBean et al. (1986).

Despite the survey sample limitations, the fieldbased method for estimating asset-level building damage ratios is potentially transferable to other locations and nonresidential building typologies. Identification of common building components, their construction cost ratios and flood damage susceptibility are key requirements for estimating asset-level damage ratios. Once derived, damage ratios will enable relationships between flood characteristics and direct tangible damage to be established for specific building typologies.

\section{Conclusions}

This study presents a post-event flood damage survey methodology to develop an empirical residential building damage database for future damage curve development. The methodological approach was to implement on-site surveys of flood damaged buildings to record flood inundation depth characteristics and physical and nonphysical building attributes, then quantify building component damage using an ordinal damage ratio scale. Quantity survey guidelines were used to convert ordinal component damage ratios into asset-level damage ratios. These ratios can be applied post-hoc analysis to establish relationships between flood characteristics and direct tangible damage for specific building typologies.

The survey methodology was applied to 674 residential buildings damaged from five major New Zealand flood events between 2013 and 2017. For twelve building typologies we observed that internal finishes including, doors, floor finishes, wall finishes, fixtures and fittings, were highly susceptible to direct damage upon contact with flood waters and indirect damage from removal and replacement during building repairs. These components comprised approximately one-third of residential building construction costs and along with service components (e.g. plumbing, electrical and heating), contributed the most to asset-level damage ratios up to $1.5 \mathrm{~m}$ above building first finished floor levels. These detailed component observations coupled with asset-level damage ratio estimates for residential building typologies could contribute towards future post-hoc empirical or synthetic methods to develop relative damage curves for residential buildings.

\section{References}

Arnell, N. W., Gosling, S. N. (2016). The impacts of climate change on river flood risk at the global scale. Climatic Change. 134: 387-401. 
Fournier, M., Larrue, C., Alexander, M., Hegger, D., Bakker, M., Pettersson, M., Crabbé, A., Mees, H., Chorynski, A. (2016). Flood risk mitigation in Europe: How far away are we from the aspired forms of adaptive governance? Ecology and Society. 21(4): 53.

Gissing, A., Blong, R. (2004). Accounting for Variability in Commercial Flood Damage Estimation, Australian Geographer. 35(2): 209-222.

Hasanzadeh Nafari, R. Ngo, T., Lehman, W. (2016). Calibration and validation of FLFArs - A new flood loss function for Australian residential structures. Natural Hazards and Earth System Science. 16: 15-27.

Jongman, B., Ward, P. J., Aerts, J. C. J. H. (2012). Global exposure to river and coastal flooding - long term trends and changes. Global Environmental Change. 22: 823-835.

Kreibich, H., Seifert, I., Merz, B., and Thieken, A. H. (2010). Development of FLEMOcs - a new model for the estimation of flood losses in the commercial sector, Hydrological Sciences Journal. 55: 1302-1314.

Kreibich, H., Thieken, A., Haubrock, S. N., Schröter, K. (2017). HOWAS21, the German Flood Damage Database, in: Flood Damage Survey and Assessment, John Wiley \& Sons, Inc., 65-75.

Laudan, J., Rözer, V., Sieg, T., Vogel, K., Thieken, A. H. (2017). Damage assessment in Braunsbach 2016: data collection and analysis for an improved understanding of damaging processes during flash floods. Natural Hazards and Earth System Science. 17,2163-2179.

Lin, S.-L., King, A., Horspool, N., Sadashiva, V., Paulik, R., Williams, S. (2019). Development and Application of the Real-Time Individual Asset Attribute Collection Tool. Frontiers in Built Environment: 5(15): 1-14.

McBean E., Fortin M., Gorrie J. (1986). A critical analysis of residential flood damage estimation curves. Canadian Journal of Civil Engineering.13: 86- 94.

Messner, F. Penning-Roswell, E. C., Green, C., Meyer, V., Tunstall, S., van der Veen, A. (2007). Evaluating flood damage: guidance and recommendations on principles and methods. FLOOD Site Project Report (2007). p. 128

Merz B., Kreibich H., Schwarze R., Thieken A. (2010). Review article "Assessment of economic flood damage". Natural Hazards and Earth System Science. 10(8):16971724.

Molinari, D., S. Menoni, G. T. Aronica, F. Ballio, N. Berni, C. Pandolfo, M. Stelluti, G. Minucci (2014). Ex post damage assessment: an Italian experience, Natural Hazards and Earth System Science. 14: 901-916.

Penning-Rowsell, E. C., Johnson, C., Tunstall, S. Tapsell, S. Morris, J. Chatterton, J., A. Coker, A., C. Green, C.
(2003). The benefits of flood and coastal defence: techniques and data for 2003, Flood Hazard Research Centre, Middlesex University, UK, 2003.

QField. Available online: https://qfield.org/, last access: 10 April 2017.

Quotable Value. QV Costbuilder. Available online: https:/qvcostbuilder.co.nz/. last access: 14 September 2017.

Thieken, A. H., M. Müller, H. Kreibich, Merz, B. (2005). Flood damage and influencing factors: New insights from the August 2002 flood in Germany. Water Resources Research. 41: W12430.

Thieken, A. H., Olschewski, A., Kreibich, H., Kobsch, S., Merz, B. (2008). Development and evaluation of FLEMOps - a new Flood Loss Estimation MOdel for the private sector, in: Flood Recovery, Innovation and Response edited by: Proverbs, D., Brebbia, C. A., and Penning-Rowsell, E., WIT Press, 315-324.

United Nations International Strategy for Disaster Reduction (2015): Sendai framework for disaster risk reduction 2015-2030. In: UN world conference on disaster risk reduction, 2015 March 14-18, Sendai, Japan. Geneva: United Nations Office for Disaster Risk Reduction; 2015. Available online: https://www.preventionweb.net/files/43291_sendaiframe workfordrren.pdf

Zhai, G. F., Fukuzono, T., Ikeda, S (2005). Modeling flood damage: Case of Tokai flood 2000, Journal of the American Water Resources Association. 41: 77-92. 